\title{
ビジネス問題に適用可能な記憶に基づく推論
}

\section{A Memory-Based Reasoning Applicable to Business Problems}

\author{
前田一穂 \\ 株式会社富士通研究所 \\ Kazuho Maeda \\ Fujitsu Laboratories Ltd. \\ maeda.kazuho@jp.fujitsu.com \\ 柳沼 義典 \\ (同上) \\ Yoshinori Yaginuma yaginuma@jp.fujitsu.com
}

Keywords: memory-based reasoning, feature weighting, classification, credit management

\section{Summary}

Recently, data mining is remarkable as a practical solution for huge accumulated data. The classification, the goal of which is that a new data is classified into one of given groups, is one of the most generally used data mining techniques. In this paper, we discuss advantages of Memory-Based Reasoning (MBR), one of classification methods, and point out some problems to use it practically. To solve them, we propose a MBR applicable to business problems, with self-determination of proper number of neighbors, proper feature weights, normalized distance metric between categorical values, high accuracy despite dependent features, and high speed prediction. We experimentally compare our MBR with usual MBR and C5.0, one of the most popular classification methods. We also discuss the fitness of our MBR to business problems, through an application study of our MBR to the financial credit management.

\section{1.はじめに}

近年 , ネットワークの発達やストレージの低価格化に より, データ蓄積が低コストで可能になり，樣々な企業 や組織で大量のデータが日々蓄積されつつある．一方， 蓄積データの活用は不十分であり, 兴の有効活用が急務 となっている. 弚の解決方法として, データから価値あ る情報を発見する「データマイニング」技術が注目され ている。

データマイニングの一分野である分類は, ある対象が あらかじめ与えられたグループのいずれに属するかの判 別が目的である. 产の手法として, 多変量解析, ニュー ラルネットワーク [Rumelhart 86] , 決定木 [Quinlan, Breiman 84]などが提案されてきた .これらは, 過去の事 例を元に問題空間を抽象化したモデルを作成し，光のモ デルに予測対象を当てはめて予測を行うため, モデルベ 一スの予測手法と呼ばれる .

一方，記憶に基づく推論(Memory-Based Reasoning : MBR)はモデルを事前に用意せず，予測時に過去の事例 から類似データを探索して予測結果を算出する手法であ る . この手法は予測過程においてモデル化による問題空 間の抽象化を伴わないため高い判別能力を有する .一方， 予測対象ごとに類似データ探索を行うため, 予測時に多
くの計算量が必要という問題点が指摘されてきたが, 計 算機性能の向上による計算時間短縮によりこの問題は解 消されつつあり, 近年この手法が注目されている .

本稿では, MBR の実用上の問題点と炎の解決方法, 実 問題での効果について述べる．以下，2 章において MBR モデルベースの予測手法と比較しつつ MBR の特徵を説 明する.さらに，3 章において実用上の問題点を指摘す るとともに, 兴の問題点の解決方法を提案し，4 章にお いて产の効果を実験により確認する．また，5 章におい て実問題への応用例として金融与信問題への適用例を示 し ,MBR がビジネスユースに適した分析手法であること を議論する。

\section{MBR の一般的な特徵と性質}

\subsection{MBR とは}

Memory-Based Reasoning(MBR)[Stanfill 86,毛利 97]とは 分類手法の一つであり, 目的変数か既知の過去の事例 (既 知事例) から, 分類したい事例 (テスト事例) に類似し た複数の事例を探索し，光の (重み付き) 多数決により 分類先を決定する手法である. 探索する類似事例の数 $(k)$ はあらかじめ設定しておく場合が多い. $k=3$ であ る簡単な例を図 1 に示す. テス卜事例に類似した 3 個の 


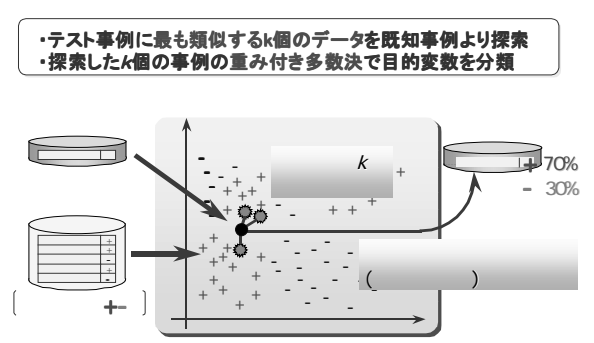

图 1 MBR の概要

事例を探索し，产の多数決 (+が 2 個，一が 1 個) によ り, + と分類している.图 1 では年齢, 職業の 2 次元 $(2$ つの説明変数) で表現したが, 実際にはより多くの説明 変数を用いて分類するのが一般的である.

MBR では 説明変数ごとにどれだけ分類に有用かとい う評価を行い, 既知事例とテスト事例間の距離計算の際 に，より有用な説明変数を重要視することで正答率を上 げようという試みがなされる．この評価値を本稿では影 響度と呼ぶ。光の一例として, cross-category feature importance(CCF)を説明する.CCF は[Stanfill 86]て提案さ れた影響度計算手法であり，式(1)で計算される。

$$
w_{i}\left(v_{i}\right)=\sum_{c} p\left(c \mid v_{i}\right)^{2}
$$

但し, $i$ は説明変数番号, $v_{i}$ はテス卜事例の説明変数 值, $c$ は目的変数値, $p(\mid)$ は既知事例集合における条件 付き確率を表す. CCF はテスト事例の説明变数值付近の 局所的な目的変数值の分布 (目的変数分布) の偏りが大 きいほど大きな值を示し，完全に等分であれば最小值を とる .

上記影響度を用いた MBR 計算方法を以下に述べる。 まず, 説明変数值 $u_{i} v_{i}$ 間の距離 $d_{i}\left(u_{i}, v_{i}\right)$ と各類似事例の 類似度 $S(u, v)$ を式(2)(3)で計算する. 但し $\sigma_{i}$ は説明変数 $i$ の標準偏差である .

$$
d_{i}\left(u_{i}, v_{i}\right)=\left\{\begin{array}{c}
\left(u_{i}-v_{i}\right) / \sigma_{i} \quad \text { (数值説明变数) } \\
\left\{\begin{array}{ll}
0 & \left(u_{i}=v_{i}\right) \\
1 & \left(u_{i} \neq \mathrm{v}_{\mathrm{i}}\right)
\end{array}\right. \text { (カテゴリ值 説明変数) }
\end{array}\right.
$$

$$
S(u, v)=1 / \sqrt{\sum_{i} w_{i}\left(v_{i}\right) \times d_{i}\left(u_{i}, v_{i}\right)^{2}}
$$

次に, 類似度による重み付き目的変数分布から確信度 を算出する.即ち, 式(3)で得られる類似度を用いて抽出 した上位 $k$ 個の類似事例について, 目的変数值ごとの類 似度の和 $T_{c}$ を求め, 式(4)により目的変数値 $c$ の確信度 $A_{c}$ を求める. 明らかに全目的変数值の確信度の和は 1 である。

$$
A_{c}=T_{c} / \sum_{d} T_{d}
$$

$T_{c}$ を最大とする $c$ がテスト事例の分類先となる.

この確信度は, 類似事例の目的変数分布から算出され るため, 確信度の值兴のものか期待值に近いことか期待 でき, また利用者が根拠(類似事例)との関係を理解しや すいという利点をもつ．

\section{2. $M B R$ の利点}

MBR はモデルベースの予測手法と異なり，モデルを用 いずデータ产のものから予測する .このことから次のよ うな利点を持っている。

1. 大量データに対して高い正答率が期待できる

2. 既知事例の増加・変化に柔軟に対応できる

1.の高い正答率の理由としては ,

- 判別関数や決定木に比へ, MBR は細かい目的変数 值間の境界線を問題空間に引くことができること [毛利 97]

・ 一般のモデルベースの手法が事例空間全体で一つ のモデルの作成するのに対し，MBR はいわばテス 卜事例ごとに局所的なモデルを作っていること が挙げられる.

2.の既知事例の変化への柔軟な対応とは, MBR は複雑 なモデル化を行わず事例を夋のまま使用するため, 既知 事例集合の変化に容易に対応できることを意味する．光 れに対し，モデルベースの分類手法では，再モデル化を 伴うため, 既知事例の増加·変化への追随に高いコスト， 手間が必要である.

\section{MBR の問題点とその解決}

我々は，MBR を実データに適用するため，MBR の問 題点を解決してきた[柳沼 98] . 解決の際には, 実データ への適用を考慮し，計算量の増加を極力抑えている. 本 章では光のいくつかを説明する．

\section{3. 影響度計算方法}

代表的な影響度計算方法である CCF の場合, 式(1)よ り明らかなように, 全体の目的変数分布を考慮しない。 実データでは目的変数と独立な説明変数がしばしば存在 するが,CCF 影響度ではこの変数の影響度が 0 とならず， この説明変数が予測結果に悪影響を及ぼす可能性がある． これを改善するため, 我々は式(5)の影響度を提案した[柳 沼 98] . (以下では newCCF と呼ぶ)

$$
\begin{aligned}
& q\left(v_{i}, c\right)=p\left(c \mid v_{i}\right) / p(c) \\
& w_{i}\left(v_{i}\right)=\frac{\sum_{c}\left|\frac{q\left(v_{i}, c\right)}{\sum_{d} q\left(v_{i}, d\right)}-\frac{1}{N_{c}}\right|}{2-\frac{2}{N_{c}}}
\end{aligned}
$$


但し, $N_{c}$ は目的変数值の数を表す.目的変数が 2 值 の場合の局所的な目的変数分布と newCCF 影響度の関係 を図 2 に示す. 横軸が局所的な目的変数分布 $(\mathrm{p}: 1-\mathrm{p})$, 縦

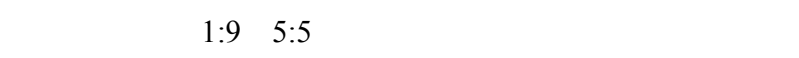
1:9，5:5 の場合の newCCF の影響度を示す . 式(5)および 一例として示した図 2 より, newCCF 影響度は以下の特 徵をもつ。

- 局所的な目的変数分布が全体の目的変数分布と等 しいとき最小值 (0) をとり，両者のずれが大きい ほど大きな值をとる.局所的に目的変数が 1 つの值 しかとらない場合, 最大値 1 をとる.この結果, 全 体の目的変数分布が考慮されていると同時に,目的 变数と独立な説明変数に対しては影響度が 0 とな り，予測結果への悪影響を回避できる.

- 全体の目的変数分布が1:9であるときの newCCF 影 響度は,最小値の右側で上向きに大きく䐍らんでい る.これは,ある少頻度な目的変数值が存在する実 データにおいて，この目的変数值が局所的に多数を 占めるケースは稀であることを踏まえている.多数 は占めなくとも全体分布より増加しているケース (図 2 における $\mathrm{p}=0.3$ 辺り)でも十分意味があり，こ のときに比較的大きな影響度を与えることで,より 高い正答率を達成することを狙っている．

\section{4. カテゴリ值間距離計算方法}

式(2)のように，通常 MBR におけるカテゴリ値間の距 離は, 異なっている場合 1,一致している場合 0 である (overlap 法)．一方で，カテゴリ值の組み合わせごとに異 なる距離を設定することにより，高い正答率を得ようと する試みもなされる .この距離を自動的に決定する方法 として，しばしばValue Difference Metric (VDM) [Stanfill 86, Scott 93]が用いられる．VDM は，各カテゴリ值にお ける目的変数值の分布の差からカテゴリ值間の距離を求 める手法であり,力テゴリ值 $v_{1} v_{2}$ 間の距離は式(6)で与え られる。

$$
d\left(v_{1}, v_{2}\right)=\sum_{c}\left(p\left(c \mid v_{1}\right)-p\left(c \mid v_{2}\right)\right)^{2}
$$

この距離は各カテゴリ值における目的変数值の分布 が一致する場合 0 であり，分布のずれが大きくなるにつ れ距離は大きくなる.最大値は 1 である.

しかし，VDM を用いても必ずしも精度が向上しない ことが知られている[Wettschereck 97]. 兴の要因として， VDM による距離が目的変数值分布の変化に対して過敏 であること，この距離が 1 よりかなり小さくなる傾向が あり, 予測結果に対するカテゴリ值説明変数の影響が数 值説明変数に比べ小さなりやすいことが挙げられる .

乥こで, 我々は正答率の向上を目指し, 以下のカテゴ リ間距離計算方法を提案する(Normalized VDM:NVDM) . まず，従来の VDM に対し，カテゴリ值間距離に対する

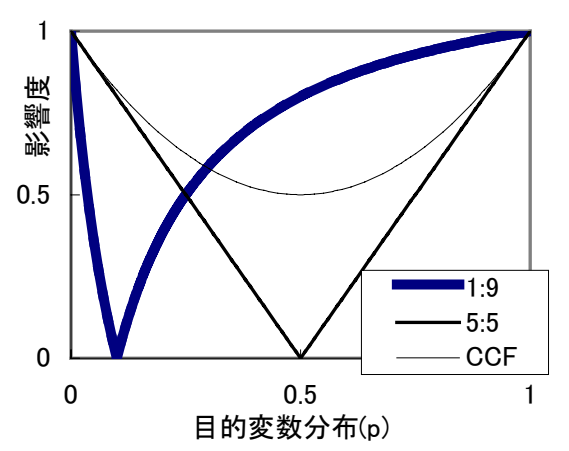

图 2 new $\mathrm{CCF}$ 影響度

目的変数值分布の影響を小さくするため平方根を取る (式(7)).さらに, 数値変数とのバランスをとるため, 異 なるカテゴリ值間の距離の平均が 1 となるよう正規化を 行う(式(8)) . 但し $N(x)$ はカテゴリ值 $x$ の頻度である .

$$
\begin{aligned}
& d_{r}\left(v_{1}, v_{2}\right)=\sqrt{d\left(v_{1}, v_{2}\right)} \\
& d_{n}\left(v_{1}, v_{2}\right)=d_{r}\left(v_{1}, v_{2}\right) / \frac{\sum_{x} \sum_{y \neq x} d_{r}(x, y) N(x) N(y)}{\sum_{x} \sum_{y \neq x} N(x) N(y)}
\end{aligned}
$$

\section{5. 独立でない説明変数の影響除去} MBR は, 各説明変数の值の差を加算する計算方法(式 (3))のため,互いに独立でない説明変数が予測に悪影響を 及ぼす可能性がある . 例えば, ある説明変数と同内容の 变数を追加すると, 本質的な問題空間は不变であるにも 関わらず, 光の説明変数の予測への影響は倍になってし まう. 分析者は重複した説明変数の探索・除去により, この悪影響を極力回避している .

一方, 主成分分析により各説明変数間の重複度を求め, それを用いて影響度を修正するアプローチもなされる。 しかし，従来手法(QM2m) [Mohri 94]では，ある累積寄与 率までの主成分を等しく使用し, 弚れ以外の主成分は使 用しないため, 適切な結果を得るためには分析者が適当 な累積寄与率を指定しなければならなかった . 乥こで, 我々は光の指定を不要とする以下の方法を提案する $(m$ は説明変数数). 以下では, 提案手法を PCA, 弚れに対 し特に影響除去しない場合を noPCA と呼ぶ。

1. 主成分分析を行い, 固有值 $\lambda_{1}, \lambda_{2}, \ldots, \lambda_{m}$ と重みべク卜 ル $\mathrm{w}_{1}, \mathrm{w}_{2}, \ldots, \mathrm{w}_{m}$ を求める . ${ }^{1}$

2. $\left\{\mathrm{w}_{i}\right\}_{j}$ を重みべクトル $\mathrm{w}_{i}$ の第 $\mathrm{j}$ 要素としたとき,式 (9)により各説明変数の修正度 $m_{j}$ を求め ${ }^{2}$, 各影響 度にこの値をかけることで修正する。 ${ }^{3}$

\footnotetext{
1 カテゴリ值変数は各变数の最小頻度值を除きダミー变数展開 しておく. $m$ はダミ一変数展開後の変数数となる .

2 カテゴリ值変数の修正度は, ダミ一変数展開後の各変数の修 正度の頻度重み付き平均により求める

3 実際には式(9)右辺の分母は常に 1 である
} 


$$
m_{j}=\left(\frac{\sum_{\lambda_{i}>1}\left\{w_{i}\right\}_{j}^{2}+\sum_{\lambda_{i} \leq 1} \lambda_{i}\left\{w_{i}\right\}_{j}{ }^{2}}{\sum_{i=1}^{m} \lambda_{i}\left\{w_{i}\right\}_{j}^{2}}\right)
$$

$\lambda_{i}$ は事例空間における第 $i$ 主成分の分散に等しく，こ れが1よりも大きいことは, 元の説明変数における第 $i$ 主 成分の重複を示す．したがって，式(9)による修正は説明 変数間の重複分だけ各变数の影響度から減じていること に相当する．

簡単な例として, 以下のような 3 数值説明変数である 既知事例集合を考える.

- 第 1 説明変数と第 2 説明変数は同一

- 第 3 説明変数は他の 2 変数と無相関

除去すべきは第 1,2 説明変数の半分である. 主成分 分析の結果，式(10)の固有値と重みベクトルが得られ， 各説明変数の修正度か計算される(式(11)).

$$
\begin{aligned}
& \lambda_{1}=2, \quad \mathrm{w}_{1}=\left(\begin{array}{c}
1 / \sqrt{2} \\
1 / \sqrt{2} \\
0
\end{array}\right), \quad \lambda_{2}=1, \quad \mathrm{w}_{2}=\left(\begin{array}{l}
0 \\
0 \\
1
\end{array}\right), \quad \lambda_{3}=0 \\
& m_{1}=\frac{1}{2}, \quad m_{2}=\frac{1}{2}, \quad m_{3}=1
\end{aligned}
$$

第 1 主成分は第 1,2 説明変数に共通して出現するた め, 弚の固有值は 2 であり, 式(11)により光の半分(重複 分)か除去される。

\section{6. 類似事例数の自動決定}

最適な類似事例数を推定する解析的な方法は知られ ていない, 兴のため, 分析者か試行錯誤の末, 類似事例 数を決定している.

我々は交差検定を用いた実験的な方法で類似事例数 を決定するアプローチをとつた，弚の際にMBR 予測で 最も計算量を必要とする類似事例の探索を効率化するた め以下の方法を用いた · [ [柳沼 98]

1. 最大類似事例数 $(K)$ を指定

2. 既知事例集合からの無作為抽出により一定事例数 $(R)$ 部分集合を作成

3. 上記部分集合の各事例について, 既知事例集合(自身 の事例は除いておく)から $K$ 個の類似事例を探索

4. 類似事例数 $(k)$ を変えながら, 光れ光れで予測

5. 正答率の移動平均が最も高い類似事例数を採用

以上の方法により，多くの類似事例数 $(k)$ を比較するに も関わらず，ほほ既知事例集合のサイズに比例する時間 で必要な類似事例を探索でき, 現実的な計算時間で類似 事例数を決定できる.

\section{7. 高速化}

MBR は午のアルゴリズムの特性上,テスト事例ごとに ぞの類似事例の探索を行わなければならず，予測時の計
算量が大きくなる．弚の処理のほとんどはテスト事例と 各既知事例間の距離計算が占める . この部分の高速化の ための前処理手法がくつか知られているが[毛利 97], これらには以下のような問題点が存在する.

・実データによく見られる多くの説明変数を持つデ ータに対し効果が見られない[Weber 98]

- 前処理を必要とするため既知事例集合の変更に迅 速に対応できない

- 前処理手法のいくつかは事例の削除を行うため, 確 信度と期待值の一致という利点がなくなる

したがって，我々は前処理を行わない，よりシンプル な以下の二方法で高速化を図った .

- 不要な類似度計算の打ち切り

- 並列化

前者は, 式(3)より，ある既知事例とテスト事例間の類 似度計算の際に 類似度が単調減少することを利用する． 即ち, 計算中の類似度力現在の類似事例集合の最小類似 度よりも小さくなった時点で, 兴の既知事例に関する計 算を打ち切り，次の既知事例の計算へ移行する .

後者は, 既知事例ごとにテスト事例との類似度計算が 独立であることを利用する . 即ち，既知事例を分割して 複数のプロセスに割り当て, 弚れ光れて類似事例集合を 求め, 最後に弚の中から全体の類似事例集合を求める. 兴の際，類似度の計算打ち切りが有効に働くよう, 適当 な間隔で, 各プロセスが持つ類似事例の類似度を交換し ている. [Maeda 97]

\section{4. 実験}

\section{8. 実験条件}

次節以降の実験にはUCI Machine Learning Laboratory[UCI]で得られるデータセット中，事例数 500 以上である 47 のデータセットを用いた(表 1). 手法間の 正答率比較では，乥れらをランダムに 10 等分した交差検 定により正答率を測定し , データセットごとにより高い 正答率を示した手法を勝ちとした . 但し，カイ2 乗検定 において，片側危険率 $50 \%$ で独立性が棄却された場合は 引分, 片側危険率 $5 \%$ て独立性が棄却された場合は優勢・ 劣勢とした .

\section{9. 類似事例数の自動決定}

類似事例数自動決定の効果を確認するため, 以下の 3 種類の方法て類似事例数を決定し, 正答率を比較した .

- 自動決定 : MBR の類似事例数自動決定機能を使用

- 従来分析 : 交差検定の各セットの既知事例集合につ

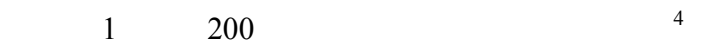

\footnotetext{
4 比較した類似事例数は $1,2,3,4,5,6,7,8,910,15,20,25,30,40,50$, $60,70,80,90,100,120,140,160,180,200$
} 
10 等分の交差検定を行い，正答率が最良であるも のを採用.従来の分析者による試行錯誤に対応する.

- 最適 : 1 から 200 までの全ての類似事例数で交差検 定を行い,正答率最良のものを採用.評価にテスト 事例の正解が必要なため, 実運用には適用不可能で あるが，参考として比較した .

他の条件は, newCCF 影響度 , overlap 法 , noPCA であ り"“自動決定”時のパラメータには, 経験上十分大きな 以下の值を指定した . ( $N$ は既知事例数 $)$

$$
K=100+\sqrt{N} / 2, \quad R=2000
$$

他の 2 手法に対する“自動決定”の比較結果を表 2 に示 す.実運用に適用不可能な“最適”には劣るが，“従来分 析”とは同程度の正答率である.一方，本実験において “従来分析”の 100 分の 1 以下の計算時間であるように, 類似事例数の決定に必要な時間と手間は“自動決定”が 少なく，実運用でば 自動決定”が有効であるといえる。

\subsection{0. 影響度計算方法}

従来の CCF 影響度と，我々ガ提案した newCCF 影響度 の正答率を比較した. 他の条件は類似事例数自動決定， overlap 法, noPCA である . newCCF 影響度の CCF 影響 度に対する優劣を表 3 に示す. 我々の提案した影響度に より，正答率の向上が確認できた .

\subsection{1. カテゴリ值間距離計算方法}

カテゴリ值間距離計算方法の効果を検証するため， overlap 法, 従来の VDM, 我々の提案した NVDM の 3 手法の正答率を比較した。他の条件は, 類似事例数自動 決定,newCCF 影響度, noPCA である .overlap 法と VDM に対する NVDM の優劣を表 4 に示す(但し，カテゴリ值 説明変数が存在しないデータセットは除外). NVDM に より, overlap 法, VDM の両者に対して正答率の向上が 確認できた .

\subsection{2. 独立でない説明変数の影響除去}

PCA の効果を測定するため, 従来手法(noPCA)との正 答率比較を行った。乥れ光れの計算方法は newCCF 影響 度, overlap 法, 類似事例数自動決定である.さらに, 各 データセットにおいて任意の一つの説明変数を 10 及び 100 重複させ,PCA と noPCA で正答率比較を行った .各 条件での noPCA に対する PCA の優劣を表 5 に示す. 元 のデータセットでは, PCA と noPCA で大きな差は見ら れない .しかし, 重複変数の増加に伴い, PCA が noPCA に対し優勢になっており,PCA が重複変数の悪影響を回 避していることが分かる.

\subsection{3. 高速化}

以下の速度測定には , 表 1 の covtype データセット(説 明変数 12 ,事例数 581,012$)$ を既知事例 9 割, テスト事例
表 1 実験に使用したデータセット

abalone adult advertisements anneal bands car cmc connect- 4 covtype crx diabetes dna flare german isolet kr-vs-kp krkopt letter lrs meta mfeat murphy mushroom musk nursery optdigits page-blocks pendigits sat segmentation shuttle spambase thyroid-allbp thyroid-allhyper thyroid-allhypo thyroid-allrep thyroid-ann thyroid-dis thyroid-hypothyroid thyroid-sick thyroid-sick-euthyroid thyroid0387 tic-tac-toe water-treatment waveform waveform-noise yeast

表 2 類似事例数自動決定 正答率比較結果

\begin{tabular}{|r|r|r|r|r|r|}
\hline & 勝 & 優勢 & 引分 & 劣勢 & 敗 \\
\hline 対従来分析 & 1 & 1 & 41 & 3 & 1 \\
\hline 対最適 & 0 & 0 & 33 & 13 & 1 \\
\hline
\end{tabular}

表 3 newCCF 影響度計算方法 正答率比較結果

\begin{tabular}{|r|r|r|r|r|r|}
\hline & 勝 & 優勢 & 引分 & 劣勢 & 敗 \\
\hline 対 CCF & 9 & 11 & 19 & 4 & 4 \\
\hline
\end{tabular}

表 4 カテゴリ值間距離計算方法(NVDM) 正答率比較結果

\begin{tabular}{|r|r|r|r|r|r|}
\hline & 勝 & 優勢 & 引分 & 劣勢 & 敗 \\
\hline 対 overlap & 3 & 2 & 23 & 0 & 1 \\
\hline 対 VDM & 5 & 5 & 13 & 5 & 1 \\
\hline
\end{tabular}

表 5 PCA の noPCA に対する正答率比較結果

\begin{tabular}{|c|r|r|r|r|r|}
\hline 重複変数数 & 勝 & 優勢 & 引分 & 劣勢 & 敗 \\
\hline なし & 2 & 3 & 37 & 5 & 0 \\
\hline 10 & 3 & 8 & 30 & 5 & 1 \\
\hline 100 & 8 & 13 & 21 & 4 & 1 \\
\hline
\end{tabular}

表 $6 \mathrm{MBR}$ 計算打ち切りあり，なしの計算時間(単位秒)

\begin{tabular}{|c|c|c|c|}
\hline & 打切あり & 打切なし & 倍率 \\
\hline 全体 & 3,383 & 15,350 & 4.54 \\
\hline 内予測部分 & 3,096 & 14,744 & 4.76 \\
\hline
\end{tabular}

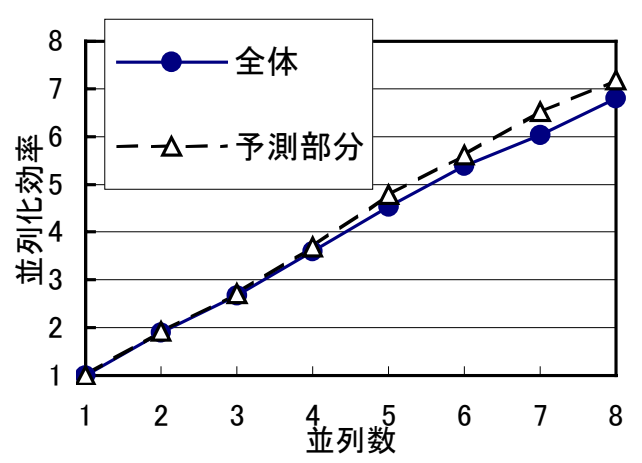

图 3 MBR 並列化効率

1 割に分割したものを用いた . 計算方法は newCCF 影響 度, overlap 法, 類似事例数自動決定, noPCA を選択, 自 動決定された類似事例数は 5 であった . なお，並列数 1 の測定には逐次実行用プログラムを使用しており，並列 処理のオーバーヘッドは含まれていない . 
まず, 計算打ち切りの効果を確認するため, 並列数 1 における計算打ち切りあり，なしの計算時間の違いを表 6 に示す. 測定には Fujitsu GP7000F モデル $400 \mathrm{~A}(300 \mathrm{MHz}$ SPARC64 GP× 2, Solaris7)を用いた . 予測部分は，全体の 実行時間から既知事例読み込みや類似事例数自動決定の 時間を除いたものであり,テスト事例数にほぼ比例する． 全体時間，予測時間とも計算打ち切りにより 4 倍以上の 高速化が得られており, 計算打ち切りの有効性を示して いる .

次に，並列化した MBR における，全体と予測部分の 並列化効率の測定結果を図 3 に示す.測定は Fujitsu GP7000S モデル 350(UltraSPARC ॥ $400 \mathrm{MHz} \times 8 \mathrm{CPU}$, Solaris7)上で, 計算打ち切りありで行った. 並列数 1 の 場合, 全体で 4,598 秒, 兴のうち予測部分は 4,225 秒であ った．全体，予測部分ともに高い並列化効率を達成でき ており，特に予測部分の場合，8 並列で 7.18 倍(589 秒) という高い並列化効率が得られた .

\subsection{4. 確信度}

次の実験では, 確信度が実際の期待值に近いことを確 認する 測定には表 1 のadultデータセット(説明変数 14 , 事例数 48,842 )を使用した .このデータセットの目的変数 值は”>50K”, ”<=50K”の 2 值である . newCCF 影響度， 類似事例数自動決定, overlap 法, noPCA を用い, 交差検 定により全事例の”>50K”確信度を計算後, 確信度を 0.1 刻みで区分し，光れ光れの区分での事例数，MBR が出力 した”>50K”確信度の平均, 目的変数值として” $>50 \mathrm{~K}$ ”を持 つ事例の割合を測定した．乥の結果を表７に示す．各区 分において確信度の平均と值” $>50 \mathrm{~K} ” の$ 割合はほぼ一致 しており ,MBR の確信度は害際の期待值に近いことか確 認できた

\subsection{5. 決定木との比較}

我々の提案した MBR(newCCF 影響度 ,NVDM noPCA， 類似事例数自動決定) と代表的な決定木の手法である C5.0[Quinlan]との間で正答率の比較を行った . C5.0 に対 する MBR の優劣を表 8 に示す. 全体として , MBR が高 い正答率を達成している.特に，MBR が劣った事例のう ち 10 個は同じデータ(thyroid)から派生したデータセット であり(これらのデータセットでは MBR の 8 敗 2 劣勢で ある), このことを勘案すると両者の差はさらに広がる． このときの決定木のサイズ(出カファイルの決定木部 分の行数 5 および光の正答率と, MBR, C5.0 間の正答率 の優劣の関係を図 4 に示す . この图では一つの点が一つ のデータセットを表している.C5.0 が優ったデータセッ 卜はこの図の左上に集中しており，右下に近づくほど MBR が優る傾向が強くなっている.

この現象は直感的に理解できる.C5.0 の決定木のサイ

5 おおよ光ノード数とリーフ数の和に等しい
表 7 確信度と実際の目的変数值確率

\begin{tabular}{|c|c|c|c|}
\hline$>50 \mathrm{~K}$ 確信度 & 事例数 & 確信度平均 & $>50 \mathrm{~K}$ 割合 \\
\hline $0-0.1$ & 24,445 & 0.02 & 0.03 \\
\hline $0.1-0.2$ & 4,976 & 0.15 & 0.14 \\
\hline $0.2-0.3$ & 3,542 & 0.25 & 0.23 \\
\hline $0.3-0.4$ & 2,787 & 0.35 & 0.32 \\
\hline $0.4-0.5$ & 2,461 & 0.45 & 0.42 \\
\hline $0.5-0.6$ & 2,210 & 0.55 & 0.51 \\
\hline $0.6-0.7$ & 2,138 & 0.65 & 0.59 \\
\hline $0.7-0.8$ & 1,988 & 0.75 & 0.70 \\
\hline $0.8-0.9$ & 1,664 & 0.85 & 0.80 \\
\hline $0.9-1.0$ & 2,631 & 0.96 & 0.96 \\
\hline
\end{tabular}

表 8 MBR のC5.0 に対する正答率比較結果

\begin{tabular}{|r|r|r|r|r|r|}
\hline & 勝 & 優勢 & 引分 & 劣勢 & 敗 \\
\hline 全データセツト & 19 & 6 & 4 & 6 & 12 \\
\hline 除 thyroid 系 & 19 & 6 & 4 & 4 & 4 \\
\hline
\end{tabular}

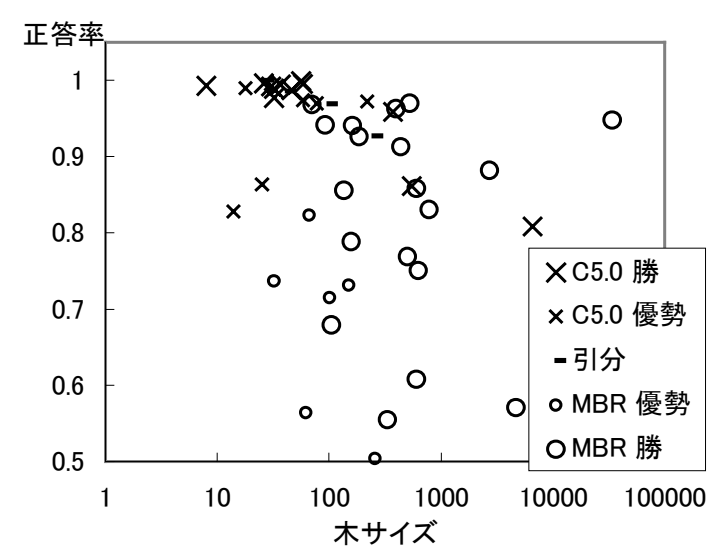

图 $4 \mathrm{C} 5.0$ 木サイズ・正答率と MBR との優劣の関係

ズは C5.0 が生成したモデルの複雑さを示していると考 えられるため, 図 5 の左上のデータセット群は, 単純な モデルで表現可能であると言える . 逆に右下に近づくほ ど複雑なモデルが必要なデータセット，あるいは C 5.0 モデルでは十分に表現できないデータセットである．し たがって，C5.0 は左上のデータセット群に対し高い正答 率を示し，反対に MBR はモデルを生成しない手法であ るため右下のデータセット群に対しても相対的に高い正 答率を維持していると考えられる 我々の経験によれば， 実データ分析では簡単なモデルでは表現不可能な複雑な 問題が多く出現する傾向にある.この点において, MBR は決定木等のモデルベースの予測手法と比較して, より 実データ向きであるといえる .

\section{5. 金融与信問題への適用}

5.16. ビジネスユースのための要件

データマイニングシステムをビジネスユースとして 
実用化, 普及させるためには, 分析者のみでなく, 分析 経験のない利用者も活用できることが重要である，我々 は, データ分析やデータマイニングシステムの顧客適用 の経験から，以下の要件を満たすことが重要であると考 える。

・ データ状況変化への対応が容易 (分析者でなくても データ更新への対応が可能)

・ データ分析手法に関する深い知見がなくても結果 の検証が可能

・ データ分析手法を用いた場合の効果の推定が容易 これらはいずれもデータ分析の一般的な要件である しかし, 一般の汎用分析システムでは, 非分析者の利用 は前提とされておらず，これらの要件を十分に満たせな い場合が多い。

以下では, 金融与信問題への適用例を通じ，MBR がこ れらの要件を満たすことを議論する .

\subsection{7. 金融与信問題とは}

金融与信問題とは, 銀行などの貸し手が，融資先にど の程度信用を供与できるかを評価することである．十分 な信用を供与できないと判断した場合には融資の停止， 融資の減額等の対応が取られる. 近年の金融自由化の中 で金融機関間の競争も激化しており，金融機関の与信問 題に対する関心も高まってきている.

以下では，樣々な金融機関において共通に扱われる， 無担保個人ローンの初期与信問題を例として取り上げる. 初期与信では, 新規顧客の融資申込みに対し，実際に融 資を行うかどうかを判断する. 以下では, 実際の分析, 運用に関して必要とされている要件についてまとめ, 光 れらについて MBR と従来のモデルベース手法との比較 を行う.

\subsection{8. 変化への的確な対応}

初期与信の目的は，借りたお金を着実に返却する顧客 に融資しつつ, 貸し倒れを引き起こす可能性が高い色険 な顧客への融資を避けることにある.特に近年, 景気や 社会構造等の樣々な状況变化が激しくなるにつれ，これ らの変化への的確な対応力強く求められている.

従来は, 多変量解析, 二ューラルネットワーク, 決定 木等のモデルベースの手法により，データを抽象化した モデルを作成し，光のモデルを用いて顧客の信用リスク を予測するのが一般的であった .この場合, 分析パラメ 一タの設定や説明変数の選択など，高い技術を持つ分析 者の多大な工数が必要となる .このため, モデルの頻繁 な更新か難しく，変化への的確な対応ができない場合が 多い。

それに対し，MBRの利用により，モデルベース手法の 場合に発生する上の問題を回避することができる .

MBR では，現状への対応は既知事例の差し替え（洗い 替え）により行われる[松本 01].この際，我々か提案し

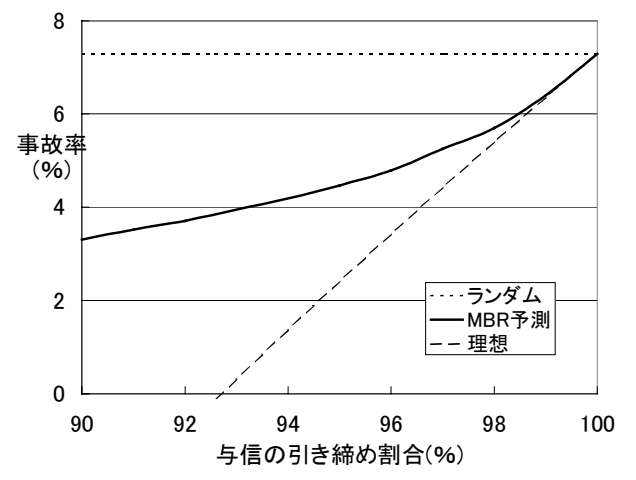

图 5 MBR 予測による効果

た手法 (影響度計算方法, 類似事例数自動決定，独立で ない説明変数の影響除去) が, 分析パラメータの設定や 説明変数の選択を不要とし，洗い替えを容易にする．

利用者は，影響度により説明されるデータの特徵や， MBR を用いて計算される効果が妥当であるかなどの結 果を検証するだけでよい．これらは，特に MBR に関す る深い理解がなくても行うことが可能である この結果， 洗い替えを高頻度で行うことができ，現状への的確な対 応が可能となる。

\subsection{MBR による効果}

人エデータを用いた実験を行い，無担保個人ローンの 初期与信における，MBR を用いたリスク管理による効果 を示す．ここでは，我々が分析した実データと同樣の効 果を示すデータを使用した .

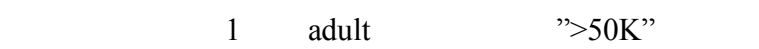
故」，"<=50K”を「正常」と置き換えて用いた .さらに，

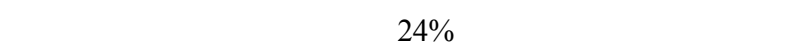
析してきた実データに比べ事故の比率が極端に高くなる ため, 事故事例の 4 分の 3 をランダムに削除し，事故の 比率を $7.3 \%$ とした .このデータに対し 10 回の交差検定 を行い, 効果を測定した。

初期与信のリスク管理の最も基本的な方法は, 危険度 が高い(MBR の場合, 事故の確信度が高い)顧客に対し， 融資を行わないことである .このことにより，実際に融 資を行った顧客の事故率を下げることができる．この樣 子を图 5 により説明する。

图 5 において, 横軸は, 現状に対してどのくらい引き 締めて融資を行うかを示す .ここで, $x \%$ 引き締め割 合とは，「事故」の確信度が高い順に(100- $x) \%$ の顧客に 対しては融資を行わず，残り $x \%$ の顧客のみに融資を行 うことを指す．縦軸は，横軸の值により与信を引き締め た場合の事故率を示す . 今回の場合 , $95 \%$ 与信引き締 めにより元の $7.3 \%$ から $4.5 \%$ に $90 \%$ の信引き締めによ り $3.3 \%$ に事故率を低下させることができる .

実際の無担保個人ローン与信の場合，危険度により， 
融資の有無のみではなく，融資限度額の上下等，より細 かなリスク管理が行われる. 产の際, 各顧客の事故の確 率が重要となるが ,MBR の確信度は期待值とほぼ一致す るため, 事故の確率を容易に推定でき, リスク管理が容 易となる．

\section{6.おわりに}

一般的な MBR の利点をまとめ, MBR を実データに適 用する際の問題点を指摘した . さらに, 兴の問題点の解 決のため, 影響度計算方法, カテゴリ值間距離の計算方 法, 類似事例数の自動決定方法, 独立でない説明変数の 影響除去方法, 計算打ち切りおよび並列化による高速化 を提案し，乥れらの効果を実験を通じて確認した．さら に,ビジネス問題への応用として金融与信問題を取り上 げ, 従来のモデルベースの予測手法に比べ我々の改良し たMBRがビジネスユースに適していることを議論した．

\section{7. 謝辞}

本研究をすすめるにあたって有益な意見をいただいた， (株)富士通研究所 池坂守夫主管研究員, 富士通(株) 新井 祥一プロジェクト部長，佐藤文信氏に深く感謝します．

\section{参考文献 $\diamond$}

[Akaike 73] Information Theory and an Extension of the Maximum likelihood principle, Second International Symposium on Information Theory, pp267-281 (1973)

[Breiman 84] Breiman, L., Friedman, J.H., Olshen, R.A. and Stone, C.J.: Classification and Regression Trees, C.J. Champion \& Hall, International Thomson, Publishing (1984)

[Cost 93] Cost, S. and Salzberg, S.: A weighted nearest neighbor algorithm for learning with symbolic features, Machine Learning, 10, pp. 57-78 (1993)

[Maeda97] Maeda, K., Yaginuma, Y. et al.: A parallel Implementation of Memory-Based Reasoning on Knowledge Discovery System, Parallel Computing Workshop '97 (PCW97), P1-I (1997)

[松本 01] 松本和宏, 前田一穂, 柳沼義典, 佐藤文信, 新井祥 一: MBR と光の金融与信問題への適用, 情報処理学会誌 7 月号 pp.696-701, Vol.42 No.7, July (2001)

[Mohri 94] Mohri, T. and Tanaka, H. 1994. An Optimal Weighting Criterion of Case Indexing for Both Numeric and Symbolic Attributes. In Aha, D. W., editor, Case-Based Reasoning: Papers from the 1994 Workshop. AAAI Press, Menlo Park, CA. TechnicalReport WS-94-01 (1994)

[毛利 97] 毛利隆夫: Nearest Neighbor 法と記憶に基づく推論, 人工知能学会誌, Vol.12, No.2, pp.188-195 (1997)

[Rumelhart 86] Rumelhart, E. et al.: Parallel Distributed Processing 1, MIT Press (1986)

[Quinlan] Quinlan, R.: Rulequest Research Home Page, http://www.rulequest.com/
[Stanfill 86] Stanfill, C. and Waltz, D.: Toward Memory-Based Reasoning, Communications of the ACM, Vol.29, No.12, pp.1213-1228 (1986)

[UCI] Merz, C. and Murphy, M.: UCI Repository of machine learning databases [http://www.ics.uci.edu/ mlearn/MLRepository.html] Irvine, CA: University of California, Department of Information (1996)

[Weber 98] Weber, R., Schek, J.H. and Blott, S.: A Quantitative Analysis and Performance Study for Similarity-Search Methods in High Dimension Spaces, Proceedings of the $24^{\text {th }}$ VLDB Conference, pp.194-205 (1998)

[Wettschereck 97] Wettschereck, D., Aha, D. and Mohri, T.: A Review and Empirical Evaluation of Feature Weighting Methods for a Class of Lazy Leaning Algorithms, Artificial Intelligence Review, vol.11, No.1-5,pp.273-314 (1997)

[柳沼 98] 柳沼義典, 前田一穂: 高性能データマイニング〜知識 発見システムの実現に向けて〜, Parallel Computing Workshop '98 Japan(PCW98Japan), DC-1 (1998)

〔担当委員：小野田 崇〕

2003 年 4 月 22 日 受理

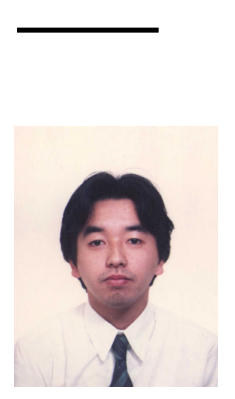

\section{著 者 紹 介}

\section{前田 一穂 (正会員)}

1994 年東京大学理学部情報科学科卒業, 1996年同大大学院理学系研究科情報科学専 攻修士課程修了。同年，株式会社富士通研 究所入社 .データマイニングアルゴリズム およびシステムの研究開発に従事 .

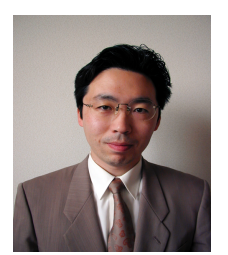

\section{柳沼 義典}

1988 年東京工業大学工学部電子物理工学科 卒業, 1990 年同大大学院総合理工学研究科 電子システム専攻修士課程修了。同年, 株 式会社富士通研究所入社 .ニューラルネッ トワーク応用 , センサフュージョンシステ ム , データマイニングアルゴリズムおよび システムの研究開発に従事 . 1999 年 2 月より 1 年間 , 英国イン ペリアル大学客員研究員. 情報処理学会, 電子通信情報学会, 各会員. 